\title{
Economic Social Relationships with Nutrition Status inTerjun Waste Disposal Place at Kelurahan Paya Pasir Medan Marelan District Year Of 2016
}

\author{
Esraida Simanjuntak ${ }^{1}$, Evawany Aritonang ${ }^{2}$, Jumirah $^{3}$ \\ ${ }^{I}$ Postgraduate Student Public Health Science University of North Sumatera, Medan, 20155, Sumatera \\ Utara,Indonesia \\ ${ }^{23}$ University of North Sumatera, Jalan Dr. T. Mansur No. 9, Medan, 20155, Sumatera Utara, Indonesia
}

\begin{abstract}
The children under years are a period where the child is experiencing a period of relatively rapid growth. One crucial factor is the nutrition factor. Nutritional status of children under five years is critical in theirgrowing process because it is the age that will determine their physical, psychological and intelligent development in the future. The objective of the research was to find out the correlation ofsocio-economy with the nutritional status of children below five years of age. It wasan analysis of a cross-sectional design, the implementation using a questionnaire. The samples were 95 children below five years old in Lingkungan I, TPA (Landfills) Terjun, Paya Pasir Village. The variables were the socio-economy and nutritional status of children under five years of age. The data analysis using chi-square test and multiple logistic regression analysis. The result showed that $54.7 \%$ of the respondents had good nutritional status. The result of chi-square test showed that there was a correlation of socio-economy with those surveyed' nutritional status. The multivariate analysis indicated that mothers' knowledge was the most dominant factor which influenced respondents' nutritional status $(\mathrm{OR}=8,2)$. Researchers suggested to the attendant health promotion along with officers nutrition providing information about the nutritional situation of children under five years and socialization to mothers in Posyandu (Integrated Health Service) Post or explanation to the parents about feeding patterns of children for five years so she can good knowledge of nutrition can reduce the incidence of children under five years and less nutrition status in children under five years through maternal or family role
\end{abstract}

Keyword: Socio-Economy, Nutritional Status, Nutrition Relationship

\section{INTRODUCTION}

The success of the development of a nation is determined by the availability of qualified human resources (HR) quality, namely human resources that have a strong physical, strong mental, excellent health, and smart. Empirical evidence indicates that good nutritional status largely determines this, and good nutritional status is determined by the amount of food intake consumed.Viewed from the point of health and nutrition problems, the toddlers included in the community groups of vulnerable groups of food, the most vulnerable groups of people affected by malnutrition, while at this time they are experiencing a relatively rapid growth process. As a result of this malnutrition susceptibility to infectious diseases can lead to an increase in infant mortality.Nutritional disorders that often occur in children is less nutrition, hunger, short, thin, obese and overweight. The prevalence of nutritional disorders in Indonesia according to Riskesdas 2013 is based on the $\mathrm{BB} / \mathrm{U}$ of which malnutrition is less $13.5 \%$, malnutrition $5.7 \%$, TB / U with short $19.2 \%$, very short $18 \%$, lean 6.8\% Very thin 5.3\%, and $11.9 \%$ grease (Riskesdas, 2013).The condition of the problem can be overcome if the government together with the family can support each other to improve the nutritional status of children under five. Several programs to improve the nutritional status have been done by the government to overcome this problem, especially in the poor-categorized family groups, but in reality, the index of nutritional status of underfive children has not shifted toward better value (Lewis, 2013).Public health conditions, an especially health of children under five years in North Sumatra Province is still far from the vision of existing health development. Various research results indicate that the factors that cause the problems of this situation are the socio-economic conditions of the family, knowledge of the mother who is still less about the pattern of care, the number of families that much, the mother's education is still low, the pattern of exclusive breastfeeding and complementary feeding of breastmilk As well as social culture that is less in harmony with the concept of health services (Purwo, 2011).Indonesia as one of the developing countries with a population of 254.9 million, environmental health problem becomes very complicated especially in the major cities like Jakarta, Surabaya, Medan, Bandung, Yogyakarta, and Semarang. One of these health problems is related to waste. Open dumping, i.e., waste does almost every place in Indonesia, the garbage disposal system is thrown away or put on the field or 
ravine without any further processing. Such exhaust systems cause contamination of air, soil, and water other than the land can also be a breeding ground for infectious disease agents (Sudradjat, 2010).

Problems occur because the garbage is not processed or processed correctly and considered completed by way of open dumping (Suyono and Budiman, 2010). The result of Meirinda's research (2008), at the 0-meter point of waste landfill in Medan Marelan sub-district, obtained the concentration of SO2, H2S, NH3 and $\mathrm{CH} 4$ gas pollutants that exceeded the quality standard. This is supported by the research of Sianipar (2009), about the risk of exposure to hydrogen sulfide $(\mathrm{H} 2 \mathrm{~S})$ average ambient air $\mathrm{H} 2 \mathrm{~S}$ concentrations exceeding the standard quality of $0.0290 \mathrm{mg} / \mathrm{m} 3$ and the standard Integrated Risk Information System (IRIS) as well as risk to health disorders In the community living in the waste landfill of Kelurahan Paya Pasir Sub-district of Medan Marelan. In addition to environmental factors in the final waste disposal site, the other issues are personal hygiene (personal hygiene) and health status.The results of the preliminary survey show that the residents pay less attention to the pattern of personal hygiene and sanitation. This is increased by the environmental conditions of dense residential houses, slums, and limited clean water due to leaching of leachate from a waste landfill to residents' wells. Residents live in densely populated homes with their families with makeshift houses. For residents who work as waste pickers also usually take home garbage to be sorted and stacked around the house so as to make the home environment is not maintained. Poor home environmental conditions and poor hygiene habits can increase the risk of disease transmission. Also, in general, the population in the neighborhood is poorly educated. A low level of education indeed determines or influences their way of thinking which will subsequently result in their health status.

\section{Problems}

Based on the background that has been described above can be seen that the question in this research is whether there is a relationship of socioeconomic, parenting, and health status with the nutritional situation of under-fives in the landfill disposal area (Waste Disposal) Kelurahan Paya Pasir Medan Marelan District 2016?

\section{Research Purposes}

This study aims to analyze the socio-economic relationships (education, employment, income, and family size, mother's nutritional knowledge) with nutritional status of under-fives in the area of waste disposal in Kelurahan Paya Pasir,

\section{Research Methods}

The type of this research is a survey, which is descriptive-analytic with cross-sectional research design. The population in this study were all children aged 0- 59 months who belong to the environment I landfill waste landfill area. Number of toddlers as many as 95 people. The sample in this study was taken from the population in total sampling, i.e. all the population tested, i.e. 95 people. Data analysis was done by using Univariate Analysis, Bivariate Analysis with Chi-Square statistical test and Multivariate Analysis with multiple logistic regression tests

\subsection{Univariate Analysis}

\section{RESULT AND DISCUSSION}

\subsection{Characteristics of Toddlers}

Toddlers who became the sample in this study as many as 95 people. Distribution of toddlers by age, mostly in the 37-59 month category with 29 people (30.5\%) and at least in the 25-36 month class of 9 people $(9.5 \%)$. The age distribution of toddlers can be seen in Table 1 below:

Table 1.Frequency Distribution by Toddler Age

\begin{tabular}{|l|c|r|}
\hline Age & Frequency & \% \\
\hline 0-6 Month & 18 & 18,9 \\
\hline 7-12 Month & 23 & 24,2 \\
\hline 13-24 Month & 16 & 16,8 \\
\hline 25-36 Month & 9 & 9,5 \\
\hline 37-59 Month & 29 & 30,5 \\
\hline Total & $\mathbf{9 5}$ & $\mathbf{1 0 0 , 0}$ \\
\hline
\end{tabular}

Distribution of frequency based on the gender of under-five, which is mostly based on male gender status is 37 people $(38,9 \%)$, while female gender is 58 persons $(61,1 \%)$, can be seen in Table 2 as follows: 
Table 2.Frequency Distribution Based on Gender of Toddler

\begin{tabular}{|l|c|r|}
\hline Gender & Frequency & \% \\
\hline Male & 37 & 38,9 \\
\hline Female & 58 & 61,1 \\
\hline Total & $\mathbf{9 5}$ & $\mathbf{1 0 0 , 0}$ \\
\hline
\end{tabular}

\subsection{Characteristics of Respondents}

The number of respondents in this study is 95 people. Unique characteristics of respondents based on mother's age, mostly in the category of 20-35 years with the number of 68 people $(71.6 \%)$, and at least in the group of 15-19 years of 2 people (2.1\%). The age distribution of respondents can be seen in Table 3 as follows:

Table 3. Frequency Distributions by Maternal Age

\begin{tabular}{|c|c|c|}
\hline Mother's Age & Frequency & \% \\
\hline $15-19$ Year & 2 & 2,1 \\
\hline $20-35$ Year & 68 & 71,6 \\
\hline $36-45$ Year & 25 & 26,3 \\
\hline Total & $\mathbf{9 5}$ & $\mathbf{1 0 0 , 0}$ \\
\hline
\end{tabular}

The characteristics of respondents based on maternal education, the most at the level of high school education as many as 40 people $(42.1 \%)$, at least at the degree of teaching has not been school as much as 2 people $(2.1 \%)$ and Universities as much as 2 people $2.1 \%$ ), can be seen more clearly in Table 4 as follows:

Table 4.Frequency Distribution by Mother Education

\begin{tabular}{|l|c|c|}
\hline Education Mother & Frequency & \% \\
\hline Never go to school & 2 & 2,1 \\
\hline Unfinished Primary School & 6 & 6,3 \\
\hline Primary School & 15 & 15,8 \\
\hline Intermediate School & 30 & 31,6 \\
\hline High School & 40 & 42,1 \\
\hline Degree & 2 & 2,1 \\
\hline Total & $\mathbf{9 5}$ & $\mathbf{1 0 0 , 0}$ \\
\hline
\end{tabular}

Characteristics of the next respondent are the work. From the interviews conducted most of the respondents who do not work as many as 54 people (56.8\%), and who work as many as 41 people (43.2\%) as table 5 below:

Table 5. Frequency Distribution Based on Mother's Work

\begin{tabular}{|l|c|c|}
\hline Job & Frequency & \% \\
\hline Working & 41 & 43,2 \\
\hline Not Working & 54 & 56,8 \\
\hline Total & $\mathbf{9 5}$ & $\mathbf{1 0 0}$ \\
\hline
\end{tabular}

The highest number of respondent's jobs is as housemaid as many as 16 people $(16,8 \%)$, and the least is the civil servant is one person $(1,1 \%)$. For more details can be seen in Table 6 below:

Table 6. Frequency Distribution by Type of Work Mother

\begin{tabular}{|l|c|c|}
\hline \multicolumn{1}{|c|}{ Type of work } & Frequency & \% \\
\hline Farmers & 4 & 4,2 \\
\hline Private employees & 8 & 8,4 \\
\hline Government employees & 1 & 1,1 \\
\hline Housemaid & 16 & 16,8 \\
\hline Scavengers & 12 & 12,6 \\
\hline Total & $\mathbf{4 1}$ & $\mathbf{1 0 0 , 0}$ \\
\hline
\end{tabular}

The income level of the family was obtained through interviews conducted with respondents, categorized based on the Regional Minimum Wage (UMR) of North Sumatera in 2016 amounting to Rp. $\leq 2,037,000$ as many as 58 people (61.1\%), and those earning $R p>2,037,000$ of 37 people ( $38.9 \%)$. The data can be seen in Table 7 as follows: 
Table 7.Distribution of Frequency Based on Family Income

\begin{tabular}{|l|c|c|}
\hline Family Income (Rp) & Frequency & \% \\
\hline Rp. $>2,037,000$ & 37 & 38,9 \\
\hline Rp. $\leq 2,037,000$ & 58 & 61,1 \\
\hline Total & $\mathbf{9 5}$ & $\mathbf{1 0 0 , 0}$ \\
\hline
\end{tabular}

In the assessment of nutritional status of toddlers, large families are also very influential. Characteristic characteristics of respondents based on the family size according to the data obtained from the interviews of those surveyed, in the big category (number of household members $>4$ people) as many as 56 people $(58.9 \%)$, and small category (number of family members $\leq 4$ persons) $(41.1 \%)$ which can be seen in Table 8 as follows:

Table 8.Distribution of Frequency by Family

\begin{tabular}{|c|c|c|}
\hline Number of Families & Frequency & \% \\
\hline Small ( $\leq$ four people) & 39 & 41,1 \\
\hline Big (>4 people) & 56 & 58,9 \\
\hline Total & $\mathbf{9 5}$ & $\mathbf{1 0 0 , 0}$ \\
\hline
\end{tabular}

The level of knowledge of mother in right category is 41 people $(43,2 \%)$, and type less than 54 people $(56,8 \%)$, can be seen in Table 9 below:

Table 9. Frequency Distribution Based on Mother's Knowledge

\begin{tabular}{|l|c|c|}
\hline Knowledge & Frequency & \% \\
\hline Good & 41 & 43,2 \\
\hline Less & 54 & 56,8 \\
\hline Total & $\mathbf{9 5}$ & $\mathbf{1 0 0 , 0}$ \\
\hline
\end{tabular}

\subsection{Nutrition Status of Toddlers}

Nutritional status is the physical condition of under-five children determined by anthropometric measurement based on Weight Index by Age (BB / U), Body Height by Age (TB / U), and Weight by Body height (BB / TB), using standard WHO-Anthro An illustration of the nutritional status of children under the age of BB / TB can be seen in Table 10 as follows:

Table 10.Frequency Distribution Based on Under five Nutrition Status Based on BB/TB

\begin{tabular}{|c|c|c|}
\hline Nutrition Status & Frequency & \% \\
\hline Normal & 52 & 54,7 \\
\hline Thin & 43 & 45,3 \\
\hline Total & $\mathbf{9 5}$ & $\mathbf{1 0 0 , 0}$ \\
\hline
\end{tabular}

The nutritional status of toddlers in Table 10 shows that the normal child nutrition status is 52 people (54.7\%) and the underweight status is 43 people $(45,3 \%)$. The description of the nutritional status of under-five children based on BB / U resulted in right category of 55 people (57,9\%), less 21 people $(22,1 \%)$, and bad for 19 people $(20,0 \%)$, for more details could be seen in Table 11 :

Table 11. Frequency Distribution Based on Under five Nutritional Status Based on BB / U

\begin{tabular}{|l|c|c|}
\hline Nutrition Status & Frequency & \% \\
\hline Good & 55 & 57,9 \\
\hline Less & 21 & 22,1 \\
\hline Bad Total & 19 & 20,0 \\
\hline \multicolumn{2}{|c|}{ T5 } & $\mathbf{1 0 0 , 0}$ \\
\hline
\end{tabular}

The description of the nutritional status of children under five TB / U, obtained the most results in the common category of 65 people $(68.4 \%)$, while the least in the high class of 2 people $(2.1 \%)$, for more details, can be seen on Table 12: 
Table 12. Frequency Distribution Based on Under five Nutritional Status Based on TB/U

\begin{tabular}{|l|c|c|}
\hline Nutrition Status & Frequency & \% \\
\hline High & 2 & 2,1 \\
\hline Normal & 65 & 68,4 \\
\hline Low & 15 & 15,8 \\
\hline Too Low & 13 & 13,7 \\
\hline Total & $\mathbf{9 5}$ & $\mathbf{1 0 0 , 0}$ \\
\hline
\end{tabular}

\subsection{Evaluation of Toddler Age with Nutritional Status}

An overview of cross-evaluation between toddler age and nutritional status of under-five children based on BB / TB can be seen in Table 13 as follows:

Table 13. Cross tabulation of Infant Age Relations with Under five Nutrition Status

\begin{tabular}{|l|l|l|l|l|l|l|}
\hline \multirow{2}{*}{ Toddler Age } & \multicolumn{4}{|c|}{ Nutrition Status } & \multicolumn{2}{c|}{ Total } \\
\cline { 2 - 7 } & \multicolumn{2}{|c|}{ Thin } & \multicolumn{2}{c|}{ Normal } & \multicolumn{2}{c|}{} \\
\cline { 2 - 7 } n & \% & n & \% & n & \% \\
\hline 0-6 Month & 8 & 44,4 & 10 & 55,6 & 18 & 100 \\
\hline 7-12 Month & 8 & 34,8 & 15 & 65,2 & 23 & 100 \\
\hline 13-24 Month & 8 & 50,0 & 8 & 50,0 & 18 & 100 \\
\hline 25-36 Month & 3 & 33,3 & 6 & 66,7 & 9 & 100 \\
\hline 37-59 Month & 16 & 55,2 & 13 & 44,8 & 29 & 100 \\
\hline
\end{tabular}

Based on table 13 it shows that at the 7-12 month age level more normal nutritional status is 15 people (65.2\%), whereas the more nutritional status is underweight at the age level of $37-59$ months by 16 people (55.2\%).

\section{Bivariate AnalysisSocio-Economic Relations with Nutritional Status of Under Five}

Based on the results of the analysis in Table 19 shows that from 59 low-educated women under five, there were $39(66,1 \%)$ children under five who had the nutritional status of underweight and 20 (33.9\%) children under normal nutritional status. Meanwhile, from 36 highly educated mothers, there were four people $(11.1 \%)$ who had nutritional status and 32 people $(88.9 \%)$ who had normal nutritional status. The results of statistical test obtained value $\mathrm{p}=<0.001$ means there is an educational relationship with nutritional status of children. From the analysis results also received the value $(\mathrm{OR}=5.6$ with $95 \% \mathrm{CI} 2,837-50,308)$ means that under-five mothers with small educational opportunities have a 5.6 times greater risk of children underweight than those with highly educated parents.Based on the results of the analysis in Table 19 shows that from 54 unworked mothers under five there is 34 people $(63 \%)$ toddler who have the nutritional status of lean and 20 people $(37 \%)$ toddler who have normal nutritional status. Meanwhile, from 41 working mothers under five years old, there were nine people $(22 \%)$ who had nutritional status and 32 people $(78 \%)$ who had normal nutritional status. Statistical test results obtained $p=<0.001$ means there is a relationship work with nutritional status of children. From the analysis results also received the value (OR $=6$ with $95 \%$ CI 2,402-15,231) means that unmarried infants have a $6 \%$ greater risk of children underweight than the working mother.

Based on the results of the analysis of Table 19 shows that from 58 mothers under five years old who have income Rp. $\leq 2.037 .000$ there is 39 people $(67,2 \%)$ Toddler which have a nutrient status of thin and 19 people $(32,8 \%)$ Toddler which have nutritional status normal. Meanwhile, from 37 mothers of under-five who have income Rp. 2,037,000, there are four people (10,8\%) of children under five who have nutritional status and $33(89,2 \%)$ who have normal nutritional status. Statistical test results obtained $p=<0.001$ means that there is an income relationship with nutritional status of children. From the analysis results also got the value $(\mathrm{OR}=6.9$ with $95 \%$ CI 2,237-54,761) means that the mother of a toddler who has an income of Rp. $\leq 2.037 .000$ have a 6.9 times greater risk of children under five undernutrition Which has an income of Rp. 2,037,000.

Based on the analysis result in Table 19 shows that from 56 mothers who have a big family of $\geq$ four people there are $32(57,1 \%)$ toddlers who have the nutritional status of underweight and $24(42,9 \%)$ toddlers who have normal nutritional status. Meanwhile, from 39 children under five who have big family <4 people there are 11 people $(28,2 \%)$ of children under five who have nutritional status and $28(71,8 \%)$ who have normal nutritional status. Statistical test results obtained $p$-value $=0.010$ means there is a large relationship family with nutritional status of children. From the analysis results also received the value (OR $=3.4$ with $95 \%$ CI 1.414 8.146) means that children with a large family of $\geq 4$ people have a 3.4 times greater risk of children underweight skinny status compared to children with a large family $<4$ people.

Based on the results of an analysis in Table 19 shows that from 54 mother toddlers who have knowledge less there is 38 people $(70,4 \%)$ Toddler which have the nutritional status of lean and 16 people $(29,6 \%)$ Toddler which have regular nutrient status. Whereas from 41 mother toddlers who have real knowledge 
there are five people $(12,2 \%)$ toddlers who have nutritional status and $36(87.8 \%)$ who have normal nutritional status. Statistical test results obtained p-value $=0.010$ means there is a relationship knowledge with nutritional status of children. From the analysis results also received the value ( $\mathrm{OR}=7,1$ with $95 \% \mathrm{CI} 4,676-51,516)$ means that under-five mother who has less knowledge have a risk chances 7.1 times bigger toddler experiencing nutritional status of thin compared to a mother of the toddler who is knowledgeable.

Table 14. Cross Sole Socio-Economic Relations with Under-five Nutrition Status

\begin{tabular}{|c|c|c|c|c|c|c|c|c|c|}
\hline \multirow[t]{3}{*}{$\begin{array}{l}\text { Independent } \\
\text { Variables }\end{array}$} & \multicolumn{4}{|c|}{$\begin{array}{c}\text { Nutritional Status of } \\
0-59 \text { Month }\end{array}$} & \multirow{2}{*}{\multicolumn{2}{|c|}{ Total }} & \multirow[t]{3}{*}{$p$-value } & \multirow[t]{3}{*}{$\begin{array}{l}\mathbf{O} \\
\mathbf{R}\end{array}$} & \multirow[t]{3}{*}{ 95\% CI } \\
\hline & \multicolumn{2}{|c|}{ Thin } & \multicolumn{2}{|c|}{ Normal } & & & & & \\
\hline & $\mathbf{N}$ & $\%$ & $\mathbf{N}$ & $\%$ & $\mathbf{N}$ & $\%$ & & & \\
\hline \multicolumn{10}{|l|}{ Education } \\
\hline Low & 39 & 66,1 & 20 & 33,9 & 59 & 100 & \multirow[t]{2}{*}{$<0,001$} & \multirow[t]{2}{*}{5,6} & \multirow[t]{2}{*}{$2,837-50,308$} \\
\hline High & 4 & 11,1 & 32 & 88,9 & 36 & 100 & & & \\
\hline \multicolumn{10}{|l|}{ Job } \\
\hline No Working & 34 & 63 & 20 & 37 & 54 & 100 & \multirow[t]{2}{*}{$<0,001$} & \multirow[t]{2}{*}{6} & \multirow[t]{2}{*}{$2,402-15,213$} \\
\hline Working & 9 & 22 & 32 & 78 & 41 & 100 & & & \\
\hline \multicolumn{10}{|l|}{ Income } \\
\hline Rp. $\leq 2,037,000$ & 39 & 67,2 & 19 & 32,8 & 58 & 100 & \multirow[t]{2}{*}{$<0,001$} & \multirow[t]{2}{*}{6,9} & \multirow[t]{2}{*}{$2,237-54,761$} \\
\hline Rp. $>2,037,000$ & 4 & 10,8 & 33 & 89,2 & 37 & 100 & & & \\
\hline \multicolumn{10}{|c|}{ Number of Families } \\
\hline Big If $\geq 4$ & 32 & 57,1 & 24 & 42,9 & 56 & 100 & \multirow[t]{2}{*}{0,010} & \multirow[t]{2}{*}{3,4} & \multirow[t]{2}{*}{$1,414-8,146$} \\
\hline Low if $<4$ & 11 & 28,2 & 28 & 71,8 & 39 & 100 & & & \\
\hline \multicolumn{10}{|l|}{ Knowledge } \\
\hline Less & 38 & 70,4 & 16 & 29,6 & 54 & 100 & \multirow[t]{2}{*}{$<0,001$} & \multirow[t]{2}{*}{7,1} & \multirow[t]{2}{*}{$4,676-51,516$} \\
\hline Good & 5 & 12,2 & 36 & 87,8 & 41 & 100 & & & \\
\hline
\end{tabular}

III. MULTIVARIATE ANALYSIS

Based on the result of the chi-square test, there are 7 (seven) variables, namely mother's education, mother's job, family income, family size, mother's knowledge, parenting, and health status has p-value $<0,25$ so that seven variables can be continued to analysis Multivariate. Multivariate analysis is an analysis to find out the correlation of independent variables, namely socioeconomic (maternal education, mother's job, family income, family size, and mother's knowledge) with the dependent variable of nutritional status of the toddler, and also know the most dominant variable related.From multivariate test by using multiple logistic regression, it is found that independent variable that is mother education, parent job, family income, mother's knowledge related to dependent variable that is nutrition status of Toddler. Test results can be seen in Table 15 below:

Table 15. Relationship of Economic Status with Under five Nutritional Status

\begin{tabular}{|l|c|c|c|c|c|}
\hline \multicolumn{1}{|c|}{ Variable independent } & B & p-value & \multirow{2}{*}{ OR } & \multicolumn{2}{c|}{$95 \%$ CI for Exp (B) } \\
\cline { 5 - 6 } & & & & Lower & Upper \\
\hline Mother Education & 1,490 & 0,024 & 5,778 & 1,574 & 32,788 \\
\hline Mother Work & 1,303 & 0,018 & 4,187 & 1,767 & 48,381 \\
\hline Family Income & 1,768 & 0,010 & 6,312 & 2,461 & 62,141 \\
\hline Mother Knowledge & 2,827 & 0,005 & 8,220 & 2,084 & 34,414 \\
\hline Constant & 2,102 & 0,001 & 0,000 & & \\
\hline
\end{tabular}

The result of multiple logistic regression analysis shows that education with p-value 0.024 , a maternal job with p-value 0,010, maternal knowledge with p-value 0,005 correlated with the nutritional status of a toddler in Final Disposal Site (TPA) Kelurahan Paya Pasir Medan Marelan District in 2016. According to Hastono (2007), to see how big the influence of variables on the dependent variable observed from OR.

Based on the results of multiple logistic regression also shows that the most dominant variable related to the nutritional status of under-five is the knowledge variable ( $p=0,005$; OR $=8,295 \%$ CI 2,084-34,414) meaning that under-five mother who have less risky opportunity 8,2 Times larger children underweight skinny nutritional status compared with well-knowledge toddler mothers. This shows that these variables have the most significant relationship to the nutritional situation of children under five years old in the landfill area Garbage Paya Pasir District of Medan Marelan Year 2016. 


\subsection{Education Relationship with Under five Nutritional Status}

The results showed that there was an association of teaching with nutritional status of under-five children $\mathrm{p}=<0.001$. From the analysis results also obtained the value $(\mathrm{OR}=5.6$ with $95 \%$ CI $2,837-50,308)$ means that low-educated toddlers have a 5.6 times greater risk of toddlers experiencing skinny nutritional status compared with high-educated toddlers. This is supported by Elfrida's study (2015) there is a relationship of maternal education with nutritional status on BGM toddlers $\{p$-value $=0.005\}$. Children with low-educated mothers have a higher mortality rate than children with well-educated mothers. A highly educated person will provide a more rational response to the information coming and will think the extent to which the benefits may be derived from the idea (Elfrida, 2015)

\subsection{Employment Relationship with Under-five Nutritional Status}

The results showed that there is a relationship of mother's work with nutritional status of children under five years old, with $p=<0,001$. From the analysis results also obtained the value (OR $=6$ with $95 \%$ CI 2,402$15,231)$ means that unmarried mother under five has risk chances six times bigger toddler experience less nutritional status compared with working mother of a toddler. This is by the results of research Dian Handini (2013) the price p count is 0.009 for sample distribution based on BB / TB.

\subsection{Income Relationship with Under-five Nutritional Status}

The results showed that there was a family income relationship with nutritional status of under-five children $\mathrm{p}=<0.001$. From the analysis results also obtained the value $(\mathrm{OR}=6.9$ with $95 \%$ CI 2,237-54,761) means that under five years old mother who has income, Rp. $\leq 2,037,000$ have risk chances 6.9 times bigger toddler experiencing nutritional status of lard compared to the mother who has Income Rp.> 2,037,000. This is in line with the study (Yuniman, 2013) which shows that there is a socioeconomic relationship with nutritional status of children $(\mathrm{p}=0.012)$. From the analysis results also obtained the value $(\mathrm{OR}=3.3$ with $95 \%$ CI 0.714 2.110) means that the mother of low-income children has a 3.3 times greater risk of children under five less nutritional status compared to mothers who have a high income.

\subsection{Large family Relationships with Under-five Nutrition Status}

The results showed that there is a great relationship family with nutritional status of children under five years old, $\mathrm{p}=0,010$. From the analysis results also obtained the value (OR $=3.4$ with $95 \%$ CI $1.414-8.146$ ) means that children with a large family of $\geq 4$ people have a 3.4 times greater risk of children under five underweight compared with the kids with large families $<4$ people. This is supported by research Sutrisno (2001) shows there is a significant relationship between the large family with the nutritional conscious family behavior. And also Mekides Wolde (2015) study showed there was a significant correlation between family size and nutritional status of children under five (OR $=3,3,95 \% \mathrm{CI}, 1,4-7,9)$, and Q.D research. Badake (2014) has a significant relationship between household size and nutritional status $(\mathrm{P}=0.047)$.

\subsection{Knowledge Relationship with Under-five Nutritional Status}

The results showed that there is a relationship of knowledge with nutritional status of children under five years old, with $\mathrm{p}=<0,010$. From the analysis results also obtained the value (OR $=7,1$ with $95 \%$ CI 4,67651,516) means that under fives mother with less knowledge have a risk chances 7.1 times bigger toddler experience less nutritional status compared with the mother of a toddler who is knowledgeable. This is supported by the results of Husnul Khotimah (2011) study that there is a significant influence on knowledge on the nutritional status of children. The calculation of the probability of Odd Ratio value (OR) is 9.8. OR results show that respondents who have below average knowledge or $\leq 14.5$ are more likely to have malnourished children under 9.8 than those with good or above average knowledge or $>14.5$. The level of knowledge determines the behavior of food consumption, one of them through nutrition education so that it will improve the food consumption habits of himself and his family (Suhardjo, 2010).

\section{CONCLUSION}

1. Nutrition status of children under five is good as much as 52 people $(54,7 \%)$.

2. $(P=0,010)$, knowledge $(p=0,010)$, parenting $(p=<0.001)$, employment $)$, Health status $(p=0,001)$ with nutritional status of children.

3. The most dominant variable related to the nutritional status of under-five children is the knowledge variable $(\mathrm{p}=0,005 ; \mathrm{OR}=8,295 \%$ CI 2,084-34,414) meaning that under-five mother of a toddler has a risk chance 8,2 times more toddler experience nutritional status Less than the well-informed mother of toddlers.

4. To the nearest health center/health worker 
It is expected that health promotion officers along with nutrition officers give counseling about status Nutrition in toddlers as well as provide socialization to Mother of Toddler at posyandu or in crowded places mothers gather or explanation to mother of toddler about pattern of feeding toddler so that mother can receive knowledge which is good about the toddler's diet and can decrease the incidence of less nutrition status in infants through the mother or family role.

5. To mother-toddler / family

a. It is expected that the mother of toddlers in order to increase their knowledge by coming to the Posyandu or the nearest health center to listen to counseling about the presentation of feeding to toddlers and families, and pay attention to the diet of children under five that is $3 \mathrm{x}$ a day with balanced nutrition, so that children do not experience less nutritional status and can bring toddlers to health services such as Posyandu, Puskesmas, Public Treatment Centers, self-employment midwives and hospitals.

b. To the family is expected to participate in improving efforts to prevent the occurrence of malnutrition in children, including by coaching and empowering families who have less nutritional risk in children. Participate in improving environmental health and caring for a healthy environment.

6. To the next researcher to add more dominant research variables related to nutritional status as well as using other research designs such as case-control to reveal factors related to nutritional status of children other than the results of this study

\section{REFERENCES}

[1]. Handini, Dian,. 2013. Hubungan Tingkat Pendapatan Keluarga Dengan Status Gizi Balita Di Wilayah Kerja Puskesmas Kalijambe Fakultas Kedokteran, Universitas Muhammadiyah Surakarta.

[2]. Lewis. 2013. Pemberian ASI eksklusif Atau MP. http://www.linkages.project.org. Diakses 15 September 2016.

[3]. Meirinda. 2008. Faktor-faktor yang Berhubungan dengan Kualitas Udara Dalam Rumah Di sekitar Tempat Pembuangan Akhir Sampah Kelurahan Terjun Kecamatan Medan Marelan, Tesis. Medan: FKM USU.

[4]. Mekides Wolde1, Yifru Berhan2* and Alemzewed Chala1 Wolde et al. Determinants of Underweight, Stunting and Wasting Among Schoolchildren. BMC Public Health.

[5]. Purwo, S, 2011. Buku Ajar Fundamental Keperawatan: Konsep, Proses, dan Praktik ed.4 vol.1, Jakarta: EGC.

[6]. Sudradjat, 2010. Mengelola Sampah Kota, Bandung: Penebar Swadaya.

[7]. Suhardjo, 2010. Berbagai Cara Pendidikan Gizi. Bogor IPB PAU Pangan dan Gizi.

[8]. Sutrisno, A., 2001. HubunganKeluargaMandiriSadarGizidengan Status GiziBalita di Kabupaten Bengkulu Utara (Analisis Data Sekunder 2000).Skripsi.Depok: FakultasKesehatanMasyarakat UI.

[9]. Suyono \& Budiman., 2010, Ilmu Kesehatan Masyarakat Dalam Kontek Kesehatan

[10]. Lingkungan, Jakarta: EGC. 